\title{
Assessing Maritime Security and Human Rights: The Role of the EU and its Member States in the Protection of Human Rights in the Maritime Domain
}

\author{
Sofia Galani \\ Lecturer in Law, University of Bristol, Bristol, United Kingdom \\ sofia.galani@bristol.ac.uk
}

\begin{abstract}
Over the years, the European Union (EU) and its Member States have taken significant steps to enhance maritime security. However, these initiatives are mostly focused on the safety of ships and the protection of the marine environment rather than the protection of human rights at sea. Without belittling the importance of these initiatives, this article argues that it is time the protection of human rights at sea was also incorporated in the efforts to enhance maritime security. This argument is supported by the analysis of the legal framework which shows that the EU and its Member States as flag, coastal or port States have assumed responsibility to protect human rights at sea under the law of the sea, human rights law and EU law.
\end{abstract}

\section{Keywords}

Charter of Fundamental Rights of the European Union - European Union (EU) human security - international human rights law - maritime security - Member States (MS) - United Nations Convention on the Law of the Sea (LOSC) 


\section{Introduction}

The protection of human rights in the maritime domain has gained considerable attention over the years. ${ }^{1}$ The drama of the hundreds of thousands of refugees trying to cross the Mediterranean Sea onboard unseaworthy vessels, ${ }^{2}$ the revelations of fishers being turned into slaves on fishing boats, ${ }^{3}$ the abuses suffered by seafarers abducted by pirates ${ }^{4}$ and the prolonged detention without judicial supervision of pirate suspects alerted the international community to the violations of human rights that take place in the maritime domain. ${ }^{5} \mathrm{We}$ are still far though from realising the nature and the scale of the abuses of persons at sea, and work needs to be done for their effective protection. This also holds true for the protection of human rights within European waters, onboard vessels that fly the flag of a Member State (MS) of the European Union (EU) or during law enforcement operations conducted by the EU naval forces or by its MS. The latter has received considerable attention in the context of anti-piracy and border control operations and will therefore not form part of the analysis of this article. ${ }^{6}$ Despite the great debate on the human rights obligations of the EU these operations have sparked, this article argues that there is a lot more we need to consider in relation to the obligations of the EU and its MS to protect human rights in the maritime domain.

As explained above, human rights violations have become all too common at sea and different groups of people, such as fishers, seafarers, or criminal suspects, can be exposed to abuses. The EU is not unaware of the increasing maritime security threats and has acknowledged that they 'pose a potential risk to

1 For an extensive study on the protection of persons at sea, see I Papanicolopulu, International Law and the Protection of People at Sea (ou P, Oxford, 2018).

2 I Mann, Humanity at Sea: Maritime Migration and the Foundations of International Law (CUP, Cambridge, 2017).

3 International Organization for Migration (IOM), Report on Human Trafficking, Forced Labour and Fisheries Crime in the Indonesian Fishing Industry (2016) available at http:// www.iom.int/sites/default/files/country/docs/indonesia/Human-Trafficking-Forced-Labou r-and-Fisheries-Crime-in-the-Indonesian-Fishing-Industry-IOM.pdf; accessed 6 July 2019.

4 S Galani, 'Somali piracy and the human rights of seafarers' (2017) 34(1) Netherlands Quarterly of Human Rights 71-98.

5 E Kontorovich, 'A Guantanamo on the sea: The difficulty of prosecuting pirates and terrorists' (2010) 98(1) California Law Review 243-275.

6 Galani (n 4) at pp. 88-9o; E Papastavridis, 'EUNAVFOR Operation Atalanta off Somalia: The EU in unchartered legal waters?' (2015) 64(3) International \& Comparative Law Quarterly 533-568; V Moreno-Law, 'Seeking asylum in the Mediterranean: Against a fragmentary reading of EU Member States' obligations accruing at sea' (2011) 23(2) International Journal of Refugee Law 174-220; N Markard, 'The right to leave by sea: Legal limits on EU migration control by third countries' (2016) 27(3) European Journal of International Law 591-616. 
European citizens and can be detrimental to the EU's and its Member States' strategic interests.' ${ }^{7}$ In its 2014 Maritime Security Strategy, the EU also took note of human rights as a founding value of the $\mathrm{EU}$ and as a guiding principle of the goals that the Strategy intended to achieve. ${ }^{8}$ However, it is the view of this author that these general references to the protection of European citizens and the human rights values of the EU can only offer some recognition but cannot effectively safeguard human rights at sea. Of its $28 \mathrm{MS}, 23$ are coastal States and are thus responsible for the control of a coastline over 90,ooo kilometres in length, which borders four seas and two oceans, and along which operate 1,200 commercial ports. In addition, Denmark, France, the Netherlands and the United Kingdom are responsible for the control of 25 Overseas Countries and Territories (OCTs), all of which are islands..$^{9}$ Of the 28 EU MS, 26 are flag States with 8,100 registered vessels (over 500 GT) and more than 80,000 fishing vessels operating worldwide, which means that hundreds of millions of people can find themselves within European waters or onboard EU-flagged vessels. ${ }^{10}$ For example, it has been estimated that more than 400 million passengers pass though EU ports every year and by the end of 2016 above a quarter of a million of seafarers had been recorded to have served onboard EU-flagged vessels." This shows that there is an urgent need to review the role of the EU and its MS in the protection of human rights not only of European citizens, but of every person who finds themselves within European waters or onboard an EU-flagged vessel, and as a result within the jurisdiction of a MS.

This article will therefore examine the duty of the EU and its MS to protect human rights at sea. It will start by discussing the definitions of maritime

7 Council of the European Union, European Union Maritime Security Strategy (11205/14) (24June 2014) at p. 7. See also European Commission, The EU Maritime Security Strategy Revised Action Plan (26 June 2018) available at https:/ec.europa.eu/maritimeaffairs/ sites/maritimeaffairs/files/eumss-revised-action-plan_en.pdf; accessed 6 July 2019.

Ibid., at pp. 3, 5 .

9 EU Commission, 'Towards an EU integrated approach to global maritime security' (6 March 2014) available at https://ec.europa.eu/fisheries/towards-eu-integrated-approach -global-maritime-security_en; accessed 8 June 2019. For the relationship between the EU and its остs, see Part Four of the Treaty on the Functioning of the European Union, OJ C 115/47 (9 May 2008) [TFEU].

10 EU Commission, ibid.

11 European Union Maritime Security Strategy, 'Responding together to Global Challenges, A Guide to Stakeholders' available at https://ec.europa.eu/maritimeaffairs/sites/maritime affairs/files/leaflet-european-union-maritime-security-strategy_en.pdf; accessed 8 June 2019, at p. 2; European Maritime Safety Agency, Seafarers Statistics in the EU (18 July 2018) available at http://emsa.europa.eu/news-a-press-centre/external-news/item/3321 -seafarer-statistics-in-the-eu-statistical-review-2016-data-stcw-is.html; accessed 8 June 2019, at p. 1 . 
security and human security at sea and by explaining their importance for the EU and its MS. The third section will examine the relevant legal framework and will explain that the EU and its MS have a duty to protect human rights at sea under the law of the sea, human rights law and EU law. Against these legal frameworks, the efforts of the EU and its MS to safeguard human rights as flag, coastal and port States will be evaluated. It will be shown that due to the European experiences, the efforts of the EU to enhance maritime security have so far been focused on making the EU fleet more competitive, promoting the safety of ships and protecting the marine environment. ${ }^{12}$ This will support the overall argument of this article that in addition to the existing maritime security initiatives, it is time the EU and its MS stepped up their efforts to harmonise and enhance the protection of human rights onboard EU-flagged vessels and within European waters.

\section{Maritime Security: An EU Perspective}

Maritime security has been described as one of the latest 'buzzwords', but there has been no international consensus on what it actually means. ${ }^{13}$ One would expect that the 1982 United Nations Convention on the Law of the Sea (LOSC) - the 'Constitution of the Oceans' - would provide some guidance on the meaning of maritime security. ${ }^{14}$ However, LOsC has scattered references to 'security' without providing any clear-cut definitions. ${ }^{15} \mathrm{~A}$ helpful guide to deconstruct the concept of maritime security could be the maritime security strategies published by various States and international organisations, including the EU. ${ }^{16}$ The common denominator in these strategies has been the

12 See, for example, the role the EU played in phasing out single-hull oil tankers from European waters, following the sinking of Prestige in V Frank, 'Consequences of the Prestige sinking for European and international law' (2005) 20(1) International Journal of Marine and Coastal Law $1-64$.

13 C Bueger, 'What is maritime security?' (2015) 53 Marine Policy 159-164, at p. 159.

14 United Nations Convention on the Law of the Sea (Montego Bay, 10 December 1982, in force 16 November 1994), 1833 UNTS 396 [LOSC].

15 S Galani and MD Evans, 'The interplay between maritime security and the 1982 United Nations Convention on the Law of the Sea: Help or hindrance?' in MD Evans \& S Galani (eds), Maritime Security and the Law of the Sea: Help or Hindrance? (Edward Elgar, Cheltenham, 2020) 8-11; N Klein, Maritime Security and the Law of the Sea (oup, Oxford, 2011) at pp. 2-11.

16 The US National Strategy for Maritime Security (September 2005) available at www.state .gov/documents/organization/255380.pdf; accessed 8 June 2019; HM Government, The UK National Strategy for Maritime Security (May 2014) available at https://assets.publishing 
listing of certain threats that undermine maritime security across the different regions. These include inter-State disputes, piracy, trafficking in drugs, people and weapons of mass destruction (WMD), illegal fishing and environmental crimes, or man-made disasters. ${ }^{17}$

Despite the general agreement on the negative impact of these threats on maritime security, the various strategies also show that maritime security is defined by the specific needs and priorities of each country or region. The recurring sovereignty disputes in Southeast Asia, for example, have prompted the Association of Southeast Asian Nations (ASEAN) to emphasise the threats posed to maritime security by military threats and inter-State disputes. ${ }^{18}$ For the African Union (AU), the weakness of African States to pass uniform legislation and the lack of funds to maintain aids to navigation have been identified among the key challenges posed to maritime security in the region. ${ }^{19}$ However, none of these seems to be a challenge for the EU. The creation of the EU represented an effort to integrate a Europe aspiring to closer economic, social, political and military ties in the aftermath of World War II which has meant that border and sovereignty disputes do not represent a major challenge for the EU. In addition, the unique legal nature of the $\mathrm{EU}$ has given it the competence to legislate and to budget for key areas across the MS, including maritime affairs, as will be discussed below. ${ }^{20}$

.service.gov.uk/government/uploads/system/uploads/attachment_data/file/310323/ National_Strategy_for_Maritime_Security_2014.pdf; accessed 8 June 2019; Government of France, National Strategy for the Security of Maritime Areas (22 October 2015) available at https://www.gouvernement.fr/sites/default/files/contenu/piece-jointe/2016/o1/strategie _nationale_de_surete_des_espaces_maritimes_en_national_strategy_for_the_security _of_maritime_areas.pdf; accessed 8 June 2019; African Union, 2050 Africa's Integrated Maritime (AIM) Strategy (29 July 2013) available at http://cggrps.org/wp-content/uploads/ 2050-AIM-Strategy_EN.pdf; accessed 8 June 2019; ASEAN Regional Forum Work Plan for Maritime Security 2018-2020 available at http://aseanregionalforum.asean.org/wp -content/uploads/2019/o1/ARF-Maritime-Security-Work-Plan-2018-202O.pdf; accessed 8 June 2019; NATO, Alliance Maritime Strategy (18 March 2011) available at https://www .nato.int/cps/ua/natohq/official_texts_75615.htm; accessed 8 June 2019. See also the African Charter on Maritime Security and Safety and Development in Africa (Lomé Charter) (2016) available at https://au.int/en/treaties/african-charter-maritime-security -and-safety-and-development-africa-lome-charter; accessed 8 June 2019 and the CARICOM Maritime and Airspace Security Cooperation Agreement, 4 July 2008, which are the first legally binding regional agreements on maritime security, but not in force yet.

17 The same threats are also identified in the UN Secretary General's Report on Oceans and the law of the sea, UN Doc. A/63/63 (10 March 2008) at pp. 18-33.

18 ASEAN Work Plan 2018-2020 (n 16) at p. 7 .

19 AIM Strategy (n 16) at para. 69; Lomé Charter (n 16) at para. 16.

$20 \quad$ NV Algemene Transport en Expeditie Onderneming van Gend \& Loos v. Netherlands Inland Revenue Administration [1963] EUECJ R-26/62 (5 February 1963) at p. 12. 
It is notable though that the EU Maritime Security Strategy is not only focused on the interests of its MS, but it also makes direct references to the importance of safeguarding the interests of European citizens while tackling maritime insecurity. ${ }^{21}$ This shows the importance the EU attaches to human security. Despite its fluid meaning, human security is considered one of the four core dimensions of maritime security along with national security, the protection of the marine environment and economic development. ${ }^{22}$ The concept of human security was first introduced in the 1994 Human Development report, which envisaged a new understanding of security focused on individuals as opposed to national security. ${ }^{23}$ Gradually, human security has been given maritime dimensions, both collectively and individually. ${ }^{24}$ The collective aspect of human security at sea refers to the economic and environmental interests of coastal communities and the risks posed to these communities by illegal fishing, environmental crimes or even piracy. ${ }^{25}$ Individual human security, on the other hand, is understood to refer to the safety and protection of seafarers from abuses onboard vessels. ${ }^{26}$ This article submits that individual human security at sea should be more broadly understood to encompass the protection of human rights of all persons at sea. Due to the nature of the employment of seafarers and the lengthy periods of time they spend onboard vessels or maritime installations, they are probably more exposed to risks of human rights abuses at sea, but there are other groups of people who also face risks of human rights violations at sea. Fishers, migrants, criminal suspects and passengers can also be affected by human rights violations and, hence, their protection should also form part of the efforts to safeguard human security at sea. ${ }^{27}$

While the references to the protection of EU citizens in the strategy are a step towards promoting human security at sea, the focus only on European citizens is narrow to say the least. The statistics discussed above show that

21 EU Maritime Security Strategy (n 17) at pp. 2-3, 6-7.

22 Bueger (n 13) at p. 161.

23 United Nations Development Programme, Human Development Report (oup, New York and Oxford, 1994) available at http://www.hdr.undp.org/sites/default/files/reports/255/ hdr_1994_en_complete_nostats.pdf; accessed 8 June 2019, at pp. 22-40. See also M Martin and T Owen, 'The second generation of human security: Lessons from the UN and EU experience' (2010) 86(1) International Affairs 211-224.

24 K Kittichaisaree, 'A code of conduct for human and regional security around the South China Sea' (2010) 32(2) Ocean Development \& International Law 131-147, at p. 133.

25 A Thorpe et al., 'Fisheries and failing States: The case of Sierra Leone' (2009) 33(2) Marine Policy 393-400; J Abbott and N Renwick, 'Pirates? Maritime piracy and societal security in Southeast Asia' (1999) 11(1) Pacifica Review: Peace, Security \& Global Change 4-24.

26 Kittichaisaree (n 24) at p. 133.

27 Papanicolopulu (n 1) at pp. 17-24. 
many people - not only European citizens - can find themselves at a daily risk of having their human rights violated within European waters. ${ }^{28}$ At the same time, a large number of people around the world face the risk of being abused onboard vessels flying the flag of a MS. It is therefore argued that the EU cannot only care for European citizens, but it has to take steps to protect the human rights of all persons within its jurisdiction.

\section{The Legal Framework}

Before we evaluate the role of the EU and its MS in the protection of human rights in the maritime domain, this section will examine where the duties of the EU and its MS derive from. It will be explained that both the EU and its MS have assumed responsibility to protect human rights under international and EU law.

\section{The 1982 LOSC}

The analysis of the legal framework shall start by discussing the obligations of the EU and its MS under the LOSC. All 28 MS have ratified the LOSC. ${ }^{29}$ In 1998, the EU became the first international organisation to ratify the Convention. ${ }^{30}$ Today, the EU remains the only international organisation to have ratified LOSC and is thus placed in a special position. While the EU did not participate in the Third United Nations Conference on the Law of the Sea (1973-1982), and the then European Economic Community (EEC) only had an observer status during the conference, the European Commission considered the ratification of the LOSC necessary. ${ }^{31}$ The participation of the EU in LOSC was facilitated by Article 305(1)(f) of the LOSC which provides that the Convention is open for signature to international organisations, in accordance with Annex IX. Article 1 of Annex IX defines an international organisation as 'an intergovernmental organisation constituted by States to which its Member States have transferred competence over matters governed by the Convention, including competence to enter into treaties in respect of those matters'. This provision

\footnotetext{
28 See the introduction of this article.

29 UN Division for Oceans Affairs and the Law of the Sea, Chronological lists of ratifications of, accessions and successions to the Convention and the related Agreements available at http://www.un.org/depts/los/reference_files/chronological_lists_of_ratifications.htm; accessed 8 June 2019 .

$30 \quad$ Ibid.

31 E Paasivirta, 'The European Union and the United Nations Convention on the Law of the Sea' (2015) 38(4) Fordham International Law Journal 1045-1071, at pp. 1047-1048.
} 
is particularly relevant to the EU for two reasons. First, the EU has the competence to ratify international agreements that bind both the EU and its MS, the so-called 'mixed agreements. ${ }^{32}$ Second, the EU has exclusive and shared competences to regulate on issues largely governed by the Losc. More specifically, the EU has exclusive competence to legislate alone on issues concerning conservation of marine biological resources under the Common Fisheries Policy. ${ }^{33}$ It also has shared competence to legislate on other matters covered by the LOSC, such as maritime transport, safety of shipping and prevention of marine pollution, and if it decides to exercise its competence, the MS have to comply with EU legislation. ${ }^{34}$

Given that both the EU and its MS are bound by the LOSC, it is worth examining what duties might arise from the Convention in terms of protecting human rights at sea. The LOSC does not have any direct references to human rights or their protection, which is unsurprising given the time the Convention was drafted and the purposes it sought to achieve. ${ }^{35}$ Nonetheless, this is not to say that the LOSC is silent on the protection of persons at sea. There are several provisions that seek to protect individuals at sea and to limit the enforcement powers of States, such as the articles that provide for assistance to persons or ships in distress, the obligation of rescue ${ }^{36}$ the duty to release vessels and crews promptly, ${ }^{37}$ and the restrictions on imprisonment penalties for fishing and pollution violations. ${ }^{38}$ In line with its LosC obligations, the EU has adopted a wide range of regulations and directives in order to protect human lives and the safety of persons at sea. ${ }^{39}$ However, these responses have certain limitations. First, general references to safety are no longer adequate to address the increasing human rights violations in the maritime domain. For example, the suffering of seafarers taken hostage by pirates or of fishers being forced to slavery cannot be tackled by references to safety. Moreover, as often happens in the law of the sea, measures are adopted to respond rather than to

32 Treaty of the European Union, oJ C 326 (26 October 2012), Article 47 [TEU]; see also C Hillion and P Koutrakos (eds), Mixed Agreements Revisited: The EU and Its Member States in the World (Hart, Oxford, 2010).

33 TEU, ibid., Article 3.

34 TEU, ibid., Article 4; TFEu (n 9), Article 91.

35 T Treves, 'Human rights and the law of the sea' (2010) 28(1) Berkeley Journal of International Law 1-14; S Cacciaguidi-Fahy, 'The law of the sea and human rights' (2007) 19(1) Sri Lanka Journal of International Law 85-108.

$36 \quad$ LOSC (n 14), Articles 18, 98, 146.

37 Ibid., Article 73.

38 Ibid., Article 240.

39 European Commission, Maritime Transport: A Selection of Essential EU Legislation Dealing with Safety and Pollution Prevention (European Union, 2016). 
prevent an accident. ${ }^{40}$ In the case of the EU, for example, the directives on the safety of ro-ro ferries were adopted in response to the sinking of MS Estonia on 28 September 1994 en route from Tallinn to Stockholm, one of the deadliest maritime accidents in European waters. ${ }^{41}$ While these measures are necessary for improving safety at sea, a more proactive approach that will prevent human rights violations at sea is needed. It is therefore argued that the LOSC cannot offer on its own the legal framework needed to holistically and effectively protect human rights in the maritime domain.

\section{Human Rights Law}

In light of the above conclusion, it is argued that the effective protection of human rights in the maritime domain requires an assessment of the duties the EU and its MS have under human rights law. It is now well-established that realising human rights at sea requires reading and applying the law of the sea and human rights law together. ${ }^{42}$ The International Tribunal for the Law of the Sea (ITLOS) has also adopted this approach, arguing that the law of the sea cannot operate in a vacuum. ${ }^{43}$ Indeed, it has been stated that due consideration has to be given to human rights during maritime law enforcement operations. ${ }^{44}$ The same approach has been adopted by human rights bodies and courts which have built a body of case law reinforcing the idea that human rights law applies at sea. In line with international human rights law and the jurisprudence on the human rights obligations of States at sea, it has been established that States have to protect the human rights of persons within their jurisdiction. In the maritime domain, States have jurisdiction in their territorial waters, onboard vessels that fly their flags and when they exercise effective control over persons at sea. ${ }^{45}$

40 F Attard, 'IMO's contribution to international law regulating maritime security' (2014) 45(4) Journal of Maritime Law \& Commerce 479-566.

$41 \quad B B C$, 'Bow door blamed for Estonia ferry disaster' (3 December 1997) available at http:// news.bbc.co.uk/2/hi/europe/36529.stm; accessed 8 June 2019; Council Directive 1999/35/ EC of 29 April 1999 on a system of mandatory surveys for the safe operation of regular ro-ro ferry and high-speed passenger craft services, OJ L 138 (1 June 1999), pp. 1-19; Directive 2003/25/EC of the European Parliament and of the Council of 14 April 2003 on specific stability requirements for ro-ro passenger ships OJ L 123/22 (17 May 2003).

42 For the discussion of an inter-regime approach, see Papanicolopulu (n 1) at pp. 80-95.

43 The M/V Saiga (No. 2) Case (Saint Vincent and the Grenadines v. Guinea) Judgment, ITLos Reports 1999, p. 10 at para. 155 .

44 Arctic Sunrise Arbitration (Netherlands v. Russia), PCA Case No 2014-02 Award on the Merits (14 August 2015) at para. 197.

45 J.H.A. v. Spain, СAT/C/41/D/323/2007 (21 November 2008), UN Committee Against Torture (UnCAT) Communication No. 323/2007; Fatou Sonko v. Spain, СAT/C/47/D/368/2008 
With reference to the MS, it is now uncontested that they remain bound by their international human rights obligations when they exercise jurisdiction in the maritime domain. In addition, MS have duties under the European Convention on Human Rights (ECHR). ${ }^{46}$ The European Court of Human Rights (ECtHR), which has probably the most advanced jurisprudence on the protection of human rights in the maritime domain, has left no room for doubt that the contracting parties remain bound by their ECHR duties when they exercise jurisdiction at sea. ${ }^{47}$ The exercise of effective control over persons at sea applies independently from the maritime zone or the flag of a vessel. In Medvedyev and others v. France, for example, in which French authorities interdicted, Winner, a Cambodian-flagged vessel suspected of drug trafficking and confining the crew aboard for a 13-day trip to a French port, it was established that

France having exercised full and exclusive control over the Winner and its crew, at least de facto, from the time of its interception, in a continuous and uninterrupted manner until they were tried in France, the applicants were effectively within France's jurisdiction for the purposes of Article 1 of the Convention. ${ }^{48}$

It might be more difficult to argue that the EU bears the same human rights obligations. The EU has not ratified any of the core UN human rights treaties. ${ }^{49}$ Despite the long-term negotiations for the accession of the EU to the ECHR, the EU has not ratified the ECHR yet. ${ }^{50}$ However, the EU is still bound by

(20 February 2012), UnCAT Communication No. 368/2008; The Haitian Centre for Human Rights et al. v. United States, Case 10.675, Report No. 51/96, Inter-American Commission on Human Rights, OEA/Ser.L/v/II.95, Doc. 7 rev. at 55 O (1997); Women on Waves v. Portugal (Application No. 31276/05) (ECtHR, 3 February 2009); Hirsi Jamaa v. Italy (Application No. 27765/o9) (ECtHR, 23 February 2012); Sharifi and Others v. Italy and Greece (Application No.16643/o9) (ECtHR, 21 October 2014); Hassan and Others v. France (Application Nos 46695/10 and 54588/10) (ECtHR, 4 December 2014).

46 European Convention for the Protection of Human Rights and Fundamental Freedoms (4 November 1950) ETS 5 .

47 See (n 45).

48 Medvedyev and Others v. France (Application No. 3394/o3) (ECtHR, 29 March 2010), para. 67. This issue is of particular importance to the obligations the EU and its MS when they conduct law enforcement operations at sea. See the discussion in the introduction of this article and at $\mathrm{n} 6$.

49 UN Office of the High Commissioner, "The core international human rights instruments and their monitoring bodies' available at http://www.ohchr.org/en/professionalinterest/ pages/coreinstruments.aspx; accessed 8 June 2018.

$5^{\circ}$ Opinion $2 / 13$ of the Court of Justice of the EU (CJEU) (18 December 2014). 
customary international law to protect human rights with peremptory character, such as torture and slavery. The Court of Justice of the EU (CJEU) has repeatedly confirmed that the EU has to respect international law, both treaty and customary, in the exercise of its powers. ${ }^{51}$ Accordingly, the EU has a duty to prevent torture and slavery within European waters or onboard vessels that fly the flag of a MS.

There is, of course, one more instrument that we could consider when examining the human rights obligations of the EU and its MS, the Charter of Fundamental Rights of the EU (the EU Charter). ${ }^{52}$ The relevance of the Charter to the protection of human rights at sea has not been carefully considered yet. ${ }^{53}$ However, the EU Charter could become a critical tool for keeping both the EU institutions and the MS in line with their human rights obligations. Article 51 of the EU Charter states that 'the provisions of this Charter are addressed to the institutions and bodies of the Union with due regard for the principle of subsidiarity and to the Member States only when they are implementing Union law'. The provision leaves no doubt that the EU institutions must comply with the EU Charter and, as a result, EU legislation on maritime affairs must also be compatible with the EU Charter obligations.

The interpretation of Article $5_{1}$ has been slightly more controversial when it comes to the duties of the MS under the EU Charter because it has not always been clear when MS implement Union law for the purposes of the provision. ${ }^{54}$ The bottom line, however, seems to be that 'the fundamental rights guaranteed by the Charter must be complied with where national legislation falls within the scope of European Union law'.55 By applying the criteria introduced in Siragusa in order to understand when national legislation falls within the

51 Case C-286/9o, Poulsen and Diva Navigation [1992] ECR I-6o19, paras. 9-10; Case C-162/96, Racke [1998] ECR I-3655, paras. 45-46; Case C-366/10, The Air Association of America, Judgment of December 2011, para. 101. See also, F Mégret and F Hoffmann, 'The UN as a human rights violator? Some reflections on the United Nations changing human rights responsibilities' (2003) 25(2) Human Rights Quarterly 314-342, at pp. 315-318.

$5^{2}$ Charter of Fundamental Rights of the European Union, OJ C 326/o2 (26 October 2012).

53 The alleged violations of the Charter mainly reach the CJEU through a preliminary reference (TEU (n 32), Article 267) and, despite improvements to the Treaty of Lisbon (Lisbon, 13 December 2007, in force 1 December 2009) (OJ C 306, 13 December 2007), it is still difficult for individuals to have their case heard by the cJEU. See G de Burca, 'After the EU Charter of Fundamental Rights: The Court of Justice as a human rights adjudicator' (2013) $20(2)$ Maastricht Journal of European \& Comparative Law 168-184, at p. 170.

54 E Hancox, "The meaning of "implementing" EU law under Article $5^{1}(1)$ of the Charter: Åkerberg Fransson' (2013) 5o(5) Common Market Law Review 1411-1431, at pp. 1418-1426.

55 Case C-617/10, Åklagaren v. Hans Åkerberg Fransson, Judgment of 26 February 2013, at para. 21. JH Reestman \& LFM Besselink, 'After Åkerberg Fransson and Melloni' (2013) 9(2) European Constitutional Law Review 169-175. 
scope of Union law - 'whether that legislation is intended to implement a provision of EU law; the nature of that legislation and whether it pursues objectives other than those covered by EU law, even if it is capable of indirectly affecting EU law; and also whether there are specific rules of EU law on the matter or capable of affecting it' - it could be concluded that national legislation adopted to implement EU legislation and policies that fall within the EU's exclusive or shared competences on maritime affairs should also comply with the EU Charter. ${ }^{56}$

One challenge that could arise with requiring the EU and its MS to comply with the EU Charter when it comes to the regulation of activities onboard vessels, in EU ports and within European waters is the territorial scope and potential extraterritorial effects of this regulation. ${ }^{57}$ The EU Charter does not have a jurisdictional clause similar to those that are found in other human rights treaties. ${ }^{58}$ To understand the territorial scope of the EU treaties, we need to look at Article 52 of the Treaty on European Union (TEU) and Article 355 of the Treaty on the Functioning of the European Union (TFEU). Article 52 of the TEU states that the EU treaties apply to the territory of MS and Article 355 of the TFEU defines the areas that are included or excluded from EU territory. However, these provisions do not provide a clear definition of the territorial scope of the EU Charter either. It is therefore suggested that we should stick to the main rule under the law of the sea and international human rights law that States remain bound by their human rights obligations when they exercise jurisdiction in the maritime domain. Accordingly, it can be argued that the EU and its MS exercise jurisdiction within European waters - ports and territorial seas - and on EU-flagged vessels and have to comply with the EU Charter.

\section{The Duties of the EU and its Member States to Protect Human Rights in the Maritime Domain}

Having examined the legal framework from which the duties of the EU and its MS to protect human rights in the maritime domain derive, this section will discuss the steps they have taken to comply with these duties and evaluate whether these steps are adequate to address human rights violations at sea. To

56 Case C-206/13, Cruciano Siragusa v. Regione Sicilia, Judgment of 6 March 2014, at para 25.

57 J Scott, 'Extraterritoriality and territorial extension in EU law' (2014) 62(1) American Journal of Comparative Law 87-125.

58 See, for example, Article 1 of the ECHR and Article 2 of the International Covenant on Civil and Political Rights (19 December 1966), 172 UNTS 1976. 
do so, the zonal approach of the LOSC will be relied upon and the rights and duties of the EU and its MS to protect human rights as coastal, port and flag States will be examined.

\section{The EU and its Member States as Flag States}

Despite the concerns that the EU fleet is declining, 30 per cent of world vessels and more than 42 per cent of seaborne trade are managed by EU shipowners. ${ }^{59}$ It has also been reported that there are more than 8,100 EU-flagged vessels (over $500 \mathrm{GT}$ ) and more than 80 ,ooo EU fishing vessels operating worldwide. ${ }^{60}$ This means that the role of the EU and its MS in the protection of human rights onboard these vessels requires special attention.

One of the key principles of the law of the sea that is 'fiercely protected' by the LOSC is the exclusive jurisdiction flag States have onboard vessels registered to their flags when sailing on the high seas. ${ }^{61}$ The LOsC gives every State coastal or landlocked - the right to grant its nationality upon a vessel. ${ }^{62}$ It also requires every flag State to 'effectively exercise its jurisdiction and control in administrative, technical and social matters over ships flying its flag'. ${ }^{63}$ Reading this provision together with the human rights principle that wants flag States to have jurisdiction onboard vessels for the purposes of enforcing human rights, it is argued that the EU and its MS have a duty to protect human rights onboard their vessels. This principle, however, which could ideally guarantee the protection of human rights on vessels, is rather problematic in practice. The core difficulty lies in the fact that some flag States, those that operate open registries in particular, are unwilling or unable to comply with their international responsibilities, including their human rights obligations. ${ }^{64}$

This difficulty is also relevant to the case of the EU and its MS undermining the effective protection of human rights onboard vessels. One of the challenges is the lack of an EU flag. Despite the efforts of the Commission to establish a Community ship registry - the 'EUROS' - which would require vessels

59 EU Guide (n 11) at p. 2. Commission communication C (2004) 43-Community guidelines on State aid to maritime transport, OJ C 13/03 (17 January 2004), p. 3.

6o EU Guide, ibid.

61 LosC (n 14), Article 52. Medvedyev and Others v. France (n 48) at para. 101. See also the discussion in R Geiss and C Tams, 'Non-flag States as guardians of the maritime order: Creeping jurisdiction of a different kind?' in H Ringbom (ed), Jurisdiction over Ships: Post-LOSC Developments in the Law of the Sea (Leiden, Brill, 2015) 19-49, at pp. 48-49.

$62 \quad \operatorname{LOSC}(\mathrm{n} 14)$, Article 91.

63 Ibid., Article 94.

64 Ademun-Odeke, 'An examination of bareboat charter registries and flag of convenience registries in international law' (2005) 36(4) Ocean Development \& International Law 339362 , at pp. $341-344$. 
of $500 \mathrm{GT}$ to fly the EU flag next to the national flag with a view to making the EU fleet more competitive, the proposal was never adopted. ${ }^{65}$ The MS and the shipping industry appeared reluctant to subscribe to unified flag rules set by the EU. ${ }^{66}$ This has meant that the MS continue to operate their own ship registries, which are subjected to different registration requirements and control standards. ${ }^{67}$ For example, Malta and Cyprus, whose accession to the EU in 2004 increased significantly the Union's share of the world's shipping, operate open registries and have flexible registration procedures. ${ }^{68}$ Open registries are known for their flags of convenience (FOCs) that appeal to shipowners who wish to avoid taxes and strict controls on their vessels. In response to the increasing number of shipowners opting for the financial benefits of FOCs, Denmark and Norway introduced the so-called second or international registry. ${ }^{69}$ This type of registry combines the characteristics of open and closed registries and has now been adopted by several other MS, including France, Germany, the Netherlands, Spain, Portugal, and the United Kingdom. ${ }^{70}$

In addition to the different ship registries operating within the EU, there is nothing to prevent EU shipowners from registering their vessels under flags outside of the EU. Indeed, Greece is an illustrative example of a thriving shipping power with vessels of Greek interests flying flags of almost 45 different States, most of them FOCs. ${ }^{71}$ This means that these vessels, although of EU interests, are subscribed to a regime which might not share the same human rights values as the $\mathrm{EU}$ and has no safeguards in place for the protection of

65 EU Commission, A Future for the Community Shipping Industry: Measures to Improve the Operating Conditions of Community Shipping (СОМ (89) 266 final) (3 August 1989) available at http://aei.pitt.edu/5699/1/5699.pdf; accessed 8 June 2019, at pp. 14-17.

66 E Watt and R Coles, Ship Registration: Law and Practice (Lloyd's Shipping Law Library) (Routledge, London, 2009) at pp. 38-39.

67 EMSA, 'An overview of the 29 European maritime administrations' available at http:// www.emsa.europa.eu/overview-maritime-administrations.html; accessed 8 June 2019; T West, 'Outflagging and Second Ship Registers: Their Impact on Manning and Employment' (European Parliament, Directorate General for Research, December 1999) (socI $107 \mathrm{EN}$ ) available at http://www.europarl.europa.eu/RegData/etudes/etudes/join/200o/ 289900/DG-4-EMPL_ET(2000)28990o_EN.pdf; accessed 8 June 2019, at pp. 12-14.

68 UnCtad, Review of Maritime Transport 2018 (UnCtAd/Rmt/2018), at pp. 29-33; R Carlisle, 'Second registers: Maritime nations respond to flags of convenience, 1984-1998' (2009) 19(3) The Northern Mariner/le marin du nord 319-340, at pp. 320-321.

69 Carlisle, ibid.; Ademun-Odeke (n 64) at pp. 340-341.

70 Ademun-Odeke, ibid.

71 N Bardounias, 'Greek-owned shipping fleet flies flags of 45 countries' Kathimerini (10 November 2005) available at http://www.ekathimerini.com/3580o/article/ekathimerini/ business/greek-owned-shipping-fleet-flies-flags-of-45-countries; accessed 8 June 2019; UNCTAD (n 68) at p. 34 . 
human rights onboard vessels. At the same time, shipping companies might seek to register their vessels under the flag of a MS mainly for the financial and trade benefits the ships registered to the EU enjoy without, however, having any link with the EU or any interest in the human rights values of the EU. ${ }^{72}$

The consequence of the lack of an EU flag and the parallel operation of different types of ship registries within the EU is that the protection of human rights onboard vessels depends on the ability and willingness of each MS to monitor and enforce human rights standards onboard vessels that fly their flags. Some flag States with stricter registration and control requirements might be more active in exercising jurisdiction and monitoring human rights standards onboard vessels, while others might appear less willing to subject their vessels to strict human rights controls. At the same time, EU shipowners can escape their human rights obligations by registering their vessels outside of the EU, while other shipping companies with questionable human and labour standards can benefit from the flag of a MS without subscribing to the values of the EU.

The competitiveness in the shipping industry has rendered the efforts of the Commission for a unified flag unsuccessful, and it is hard to believe that such an initiative would succeed any time soon. This, however, does not mean that the EU is powerless to harmonise the protection of human rights onboard EU-flagged vessels. The economic incentives and trade benefits that EU-flagged vessels enjoy should be accompanied by stricter requirements regarding the protection of human rights and the failure to comply with human rights obligations should result in losing out on these privileges. One such requirement could be the effective implementation of Regulation 5.1.5 of the Maritime Labour Convention, 2006 (MLC 2006) which introduced onboard complaint procedures intended to enable seafarers to lodge complaints relating to any matter that is alleged to constitute a breach of the requirements of the MLC $2006 .^{73}$ Under this regulation, flag States have a duty to implement a mechanism for the fair, effective and expeditious handling of seafarer complaints on flag States. In case a seafarer cannot have his/her complaint reviewed under this mechanism, (s)he should be able to access national courts. This would

72 See, for example, the Commission communication C (2004) 43 (n 59). The EU has also entered into several trade agreements with non-EU countries that offer EU-flagged vessels easier access to their ports or allow cabotage in their waters. See, for example, the Agreement establishing an association between the EC and its Member States and the Republic of Chile (2004) and the Trade Agreement between the European Union and its Member States, of the one part, and Colombia and Peru, of the other part.

73 Maritime Labour Convention, 2006 (Geneva, 23 February 2006, in force 20 August 2013), 45 ILM 792 (2006) [MLC 2006]. 
require all MS to ensure that their national legislation applies onboard vessels flying their flags empowering national courts to review relevant complaints. The enhanced port State control (PSC) exercised by the EU, discussed below, could also be used to fill in the gaps left by the failure of flag States to protect human rights onboard the vessels that fly their flags.

\section{The EU and its Member States as Coastal States}

Having looked at the duties of MS to protect human rights as flag States and the challenges that arise from the lack of a unified EU flag, it is time to examine their duties as coastal States. The rights and obligations of coastal States within their territorial sea, their exclusive economic zone (EEZ) and continental shelf are largely regulated by the LOSC. As noted above, however, in order to understand the human rights obligations of the EU and its MS as coastal States it is necessary to consider the human rights framework, and the discussion below will also be informed by human rights law.

\section{Territorial Sea}

The obligation of the EU and its MS to protect human rights within their territorial waters could be largely uncontroversial, had it not been limited by navigational rights, which also hold an important place in the Losc. ${ }^{74}$ Under Article 2 of the LOSC, it is established that coastal States have sovereignty over the $12 \mathrm{~nm}$ that form their territorial sea. This means that coastal States enjoy extensive sovereign rights over their territorial waters that are comparable to the sovereign rights they enjoy on land. It is also unquestionable that people within the territorial waters of the EU are within its jurisdiction for the purposes of human rights, and the EU and its MS have to respect and protect their rights. The right of coastal States, however, to enforce human rights within their territorial sea is curbed by the right of innocent passage. The right of innocent passage represents one of the core values of the freedom of navigation and is explained in Article 19 of the LOSC as a passage 'not prejudicial to the peace, good order or security of the coastal State'. Its protection is reinforced by Article 27 of the LOSC. This provision does not permit coastal States to exercise criminal jurisdiction 'onboard a foreign ship passing through the territorial sea to arrest any person or to conduct any investigation in connection with any crime committed onboard the ship during its passage' save in clear-cut exceptions, which include crimes with consequences extending to the coastal

74 Y Tanaka, 'Navigational rights and freedoms' in D Rothwell, A Oude Elferink, K Scott, and T Stephens (eds), The Oxford Handbook of the Law of the Sea (ou P, Oxford, 2015) 536-558, at pp. $536-537$. 
State or which can disturb the peace or good order of the territorial sea, or in case the master of the ship or a flag State representative has requested assistance, or if such measures are necessary for the suppression of illicit drug trafficking. The exceptions listed by Article 27 do not refer to human rights violations committed onboard a vessel, and it would be far-fetched to argue that human rights violations have consequences for or affect the good order of a coastal State. As a result, a coastal State would be able to intervene only if the master or a flag State official requested help. This provides some potential for the conduct of an investigation and subsequent criminal enforcement action against human rights violations taken by coastal States, but the effectiveness of the provision relies on the will of the master of the ship or flag State officials to report the problem and request assistance. Unfortunately, the wording of the provision seems to suggest that if the crew or the passengers of a vessel notify the coastal State of human rights abuses, the MS might not have the legal basis to intervene.

To mitigate this problem, one could explore the possibility of characterising the violations of human rights law as not innocent passage. Given that the LOSC is a 'living treaty' and Article 19(2) does not provide an exhaustive list of activities not constituting innocent passage, severe human rights violations could be considered prejudicial to coastal States. ${ }^{75}$ Admittedly, this approach could open Pandora's box and allow severe interference with the freedom of navigation, but it could act as a counterpart to the failure of flag States to enforce human rights onboard their vessels. A less controversial alternative could be that coastal States could exercise jurisdiction over crimes of torture and slavery committed onboard vessels passing through their territorial sea because of the jus cogens nature of these rights. ${ }^{76}$ In this case, MS notified of abuses onboard vessels that amount to torture or of slavery practices could inspect the vessel and investigate any violations.

\section{EEZ}

Coastal States have fewer powers within the $200 \mathrm{~nm}$ of their EEZ as their sovereign rights are limited to 'exploring and exploiting, conserving and managing the natural resources' within this zone. ${ }^{77}$ The jurisdiction they can exercise is limited to performing exploration and exploitation activities and

75 J Barrett and R Barnes (eds), Law of the Sea: LOSC as a Living Ttreaty (BIICL, London, 2016); H Yang, Jurisdiction of the Coastal State over Foreign Merchant Ships in Internal Waters and the Territorial Sea (Springer, Berlin, 2006) at pp. 145-149.

76 Papanicolopulu (n 1) at p. 140.

$77 \quad$ LOsC (n 14), Article 56. 
is restrained by the freedom of navigation and the jurisdiction of the flag State. ${ }^{78}$ From a human rights perspective, this means that what the EU and its MS can do in order to protect human rights within the EEZ is rather limited. However, it has been explained that illegal fishing, which mostly takes places within $200 \mathrm{~nm}$ of coastal States, is linked to severe human rights abuses with fishers being subjected to torture and slavery. It is therefore important to examine whether there is room for protecting fishers operating within the EEZs of a MS against human rights abuses on the basis of the existing framework.

The EU has exclusive competence on fisheries and over the years it has developed the Common Fisheries Policy (CFP) for managing fishing fleets and conserving fish stocks. ${ }^{79}$ In addition, the CFP is aimed at ensuring equal access to all European fishing fleets to EU waters and fair competition. The CFP has a strong emphasis on the conservation of fisheries that is unsurprising considering that the LosC provisions also seek to optimise fishing in a sustainable manner. ${ }^{80}$ However, there are no specific provisions intended to protect human rights onboard vessels. This comes to stark contrast to the clause concerning respect for human rights included in all protocols to the EU Sustainable Fisheries Partnership Agreements, which the Commission has concluded with non-member countries and allow EU-flagged fishing vessels to fish for surplus stocks in the EEz of these countries. Distant fishing in the EEZs of lower income countries, mainly African countries, could allow for the exploitation of human rights and thus, the EU has sought to create a legally regulated environment that can protect human rights as well as sustainable fishing. ${ }^{81}$ In the same sense, it is suggested that the EU could equally act to put safeguards in place for the protection of human rights of fishers onboard boats operating within the EEZs of its own MS. Turning a blind eye to the abuse of fishers within the EEZs of MS so long as they comply with the conservation rules of the CFP can no longer be an acceptable approach. The EU should therefore use the powers it has under Article 73 of the LOSC to inspect human

$78 \quad$ Ibid., Article 58.

79 TFEu (n 9), Articles 38-43. See also, European Parliament, The Common Fisheries Policy: Origins and development (Fact Sheets on the EU 2019) available at http://www.europarl .europa.eu/ftu/pdf/en/FTU_3·3.1.pdf; accessed 8 June 2019.

8 o $\quad$ LOSC (n 14), Articles 61, 62 .

81 Directorate-General for Maritime Affairs and Fisheries (European Commission), EU Sustainable Fisheries Partnership Agreements (European Union, 2017) available at https:// publications.europa.eu/en/publication-detail/-/publication/c8b5d962-od38-11e7-8a35 -o1aa75ed71a1/language-en/format-PDF/source-3790703o; accessed 8 June 2019. 
rights onboard vessels that fish within the EEZ of MS and ban access to boats that do not comply with human rights standards. ${ }^{82}$

\section{Platforms and Maritime Installations}

One category of people that is often overlooked when we talk about human rights at sea are those who work on platforms or other maritime installations. As happens with seafarers and fishers, people employed to work on platforms and installations are usually far from land and might have their human rights violated without any monitoring or inspections. Articles 60 and 80 of the LOSC provide that coastal States have exclusive jurisdiction over artificial islands, installations and structures in the EEZ and on the continental shelf. This means that the EU and its MS should be responsible for protecting the human rights of those working on maritime installations within the EEZ and continental shelf of a MS. Indeed, in Salemink, the CJEU found that the EU legislation on social security applies to persons employed on a platform built within the continental shelf of the Netherlands. ${ }^{83}$ The case is reassuring in that these people are also covered by EU law, including the EU Charter.

\section{The EU and its Member States as Port States}

In the introduction of this article, it was noted that there are 1,800 ports and harbours within the EU, which means that the EU and its MS have strategic interests as port States. Ports are essentially within the EU internal waters. It is therefore uncontested that port States can enforce domestic legislation upon vessels that voluntarily enter the territory of a MS. ${ }^{84}$ Under the law of the sea, port States have jurisdiction mostly on issues relating to the safety and security of vessels and the protection of the marine environment. ${ }^{85}$ The exercise of PSC, however, has come under strict scrutiny because of its extraterritorial effects. ${ }^{86}$ While port States can regulate issues relating to the vessels that enter

\footnotetext{
82 Papanicolopulu (n 1) at pp. 141-142.

83 Case C-347/10, A. Salemink v. Raad van bestuurvan het Uitvoeringsinstituut werknemersverzekeringen, Judgment of 17 January 2012 at paras. 30-31.

84 V Lowe, 'The right of entry into maritime ports in international law' (1977) 14(3) San Diego Law Review 597-622.

$85 \operatorname{LOSC}(\mathrm{n} \mathrm{14})$, Articles 25, 211, 219; International Convention for the Safety of Life at Sea (London, 1 November 1974, in force 25 May 1980), $1184 \operatorname{UNTS}_{3}$, as amended, Chapter 1, Regulation 19; International Convention for the Prevention of Pollution from Ships as modified by the Protocol of 1978 (London, 2 November 1973, in force 2 October 1983), 1340 UNTS 184, Article 5; MLC 2006 (n 73), Article v(4).

86 For a definition of the term PSC, see Y Yu, Y Zhao, and YC Chang, 'Challenges to the primary jurisdiction of flag states over ships' (2018) 49(1) Ocean Development \& International Law 85-102, at p. 87 .
} 
their ports, they might end up exercising jurisdiction over activities or crimes that took place before a vessel entered their port, such as discharge of toxic waste on the high seas or illegal fishing in the EEz of another coastal State. ${ }^{87}$ Despite some criticisms, there has been an emerging school of thought which supports the idea that 'responsible port States' should exercise jurisdiction over crimes against global commons, such as fisheries and the marine environment, especially in cases where flag States fail to act. ${ }^{88}$

In the context of human rights, the exercise of jurisdiction onboard vessels entering the port of a State should be less controversial. Human rights abuses onboard these vessels are in breach of the port State's human rights obligations and as a result, the port State should be able to intervene. ${ }^{89}$ While a port State might not be able to exercise jurisdiction for violations of human rights committed when the vessel was on the high seas or within the jurisdiction of another coastal or port State, it should be able to exercise its jurisdiction over continuing abuses or abuses that started when the vessel entered its port. Accordingly, vessels voluntarily entering EU ports should comply with the EU human rights standards, and the EU and its MS should be able to inspect and enforce human rights onboard these vessels.

The EU has been active in protecting port security and gradually the protection of human rights could also be incorporated in port security measures. The EU has sought to enhance port security through its participation in the Paris Memorandum of Understanding (Paris MoU). The drafting and adoption of the Paris MoU was triggered by the sinking of the crude oil tanker Amoco Cadiz in 1978 which resulted in a massive oil spill off the French coasts. ${ }^{90}$ In addition to the $25 \mathrm{EU}$ port States, the European Commission is also a member of the

87 EJ Molenaar, 'Port state jurisdiction: Towards mandatory and comprehensive use' in David Freestone, Richard Barnes, and David Ong (eds), The Law of the Sea Progress and Prospects the Law of the Sea: Progress and Prospects (oup, Oxford, 2006) 193-209, at pp. 197-203.

88 S Kopela, 'Port-state jurisdiction, extraterritoriality, and the protection of global commons' (2016) 47(2) International Journal of Marine and Costal Law 89-130; EJ Molenaar, 'Port State jurisdiction: Toward comprehensive, mandatory and global coverage' (2007) 38(2) International Journal of Marine and Costal Law 225-257.

89 U Khaliq, 'Jurisdiction, ships and human rights treaties' in Ringbom (ed) (n 61) 324-36o, at p. 33 o.

90 J van Leeuwen, 'The regionalization of maritime governance: Towards a polycentric governance system for sustainable shipping in the European Union' (2015) 117 Ocean \& Coastal Management 23-31, at p. 27. The adoption of the Paris MoU triggered the adoption of several other regional initiatives on PSC. See HS Bang and DJ Jang, 'Recent developments in regional memorandums of understanding on port State control' (2012) 43(2) Ocean Development \& International Law 170-187. 
Port State Control Committee (PSCC), the executive body of the Paris MoU. The role of the PSCC is to inspect vessels entering the ports of the participating States to ensure compliance with safety, security, environmental and labour standards. The Paris MoU is aimed at eliminating the entry and operation of sub-standard vessels within the ports of participating States through publicising the findings of the inspections, naming and shaming those shipowners who fail to meet the international standards of safety and security and occasionally by detaining their vessels..$^{91}$ The EU has further supplemented port security efforts by adopting legislation to enhance the safety and efficiency of maritime traffic through a vessel traffic monitoring and information system and by reducing sub-standard vessels within European waters. ${ }^{92}$

In the case of the EU, this harmonised system is of particular importance as it can also eliminate port shopping practices and effectively enforce maritime security standards across the EU ports. ${ }^{93}$ The focus of the Paris MoU is not on human rights, but the power it gives to the EU and its MS to inspect labour conditions could be a first step towards enhancing the living and working standards of seafarers onboard vessels. While labour rights are not strictly speaking human rights, some labour rights are also recognised and protected by human rights treaties, and this could contribute to an emerging recognition and protection of human rights standards onboard vessels. ${ }^{94}$ The MLC 2006 is one of the core labour conventions that must be complied with onboard vessels, and is used to measure the labour standards as part of the Paris MoU inspections. In addition, port States might be able to assist seafarers lodging complaints onboard vessels while in port under Regulation 5.1.5 and intervene in cases where they are victimised as a result of their complaints. ${ }^{95}$ Victimisation is defined to cover 'any adverse action taken by any person with respect to a seafarer for lodging a complaint which is not manifestly vexatious or maliciously made' and could include acts in violation of seafarers' human rights. ${ }^{96}$ Whereas the EU has not ratified the MLC 2006 and is not a party to the International Labour

91 See the inspections database available at http://www.parismou.org/inspection-search/ inspection-search; accessed 8 June 2019.

92 Directive 2009/16/EC of the European Parliament and of the Council of 23 April 2009 on port State control, OJ L 131 (28 May 2009); Directive 2002/59/EC of the European Parliament and of the Council of 27 June 2002 establishing a Community vessel traffic monitoring and information system and repealing Council Directive 93/75/EEC, OJ L 208/10 (5 August 2002).

93 Bang and Jang (n 9o) at p. 171.

94 VMantouvalou, 'Are labour rights human rights?' (2012)3(2) European Labour Law Journal 151-172.

95 See the discussion above.

$96 \quad$ MLC 2006 (n 73), Standard A5.15, para. 3. 
Organization either, it has transposed large parts of the Convention into EU law which has been further supplemented by social security measures aimed at protecting those working within the EU maritime transport sector. ${ }^{97}$ The EU and its MS should therefore inspect and enforce labour standards onboard vessels entering their ports.

The Paris MoU and the exercise of PSC have been effective tools for enforcing safety and pollution prevention standards and enhancing maritime security within the EU.98 Inspecting and enforcing the MLC 2006 standards onboard vessels have also been significant in terms of enhancing the living and working conditions of seafarers. The EU has further invested in the effective implementation of the Paris MoU by establishing the European Maritime Security Agency (EMSA), which provides technical support and exchanges information with the maritime authorities of the MS. ${ }^{99}$ However, for the time being these efforts lack a focus on the protection of human rights that can no longer be justified in light of the increasing human rights violations and the failure of some flag States to act to protect them. This article therefore submits that the inspection of human rights standards should also form part of the Paris MoU procedures and the findings should also be publicised and become part of the performance standards of ships.

\section{Conclusion}

This article highlighted the strain under which the human rights of persons at sea have come because of the increasing threats posed to maritime security. It was explained that the EU is aware of these threats and has adopted various initiatives to tackle them. Most of these initiatives, however, were adopted to make the EU fleet more competitive, to protect safety at sea or to enforce marine environmental standards. This has meant that human security at sea has so far been overlooked by the EU and its MS. It is therefore argued that it

97 Council Directive 2009/13/EC of 16 February 2009 implementing the Agreement concluded by the European Community Shipowners' Associations (ECSA) and the European Transport Workers' Federation (ETF) on the Maritime Labour Convention, 2006, and amending Directive 1999/63/EC, OJ L 124/30 (20 April 2009); Directive 2008/106/EC of the European Parliament and of the Council of 19 November 2008 on the minimum level of training of seafarers (recast), OJ L 323 (3 December 2008).

98 B Tzarnoretchka, Implementation and Effects of the Third Maritime Safety Package: Ex-Post Impact Assessment (European Parliament, October 2015) available at http:// www.europarl.europa.eu/RegData/etudes/STUD/2015/536331/EPRS_STU(2015)536331 _EN.pdf; accessed 8 June 2019, at pp. 6-9.

Ibid., at p. 10. 
is time to incorporate the protection of human rights in the efforts of the EU to enhance maritime security. The examination of the relevant legal framework lends support to this argument as it was demonstrated that the EU and its MS have assumed responsibility to protect human rights under the law of the sea, human rights law and EU law. The EU and its MS have both strategic interests in maritime security and an important role to play in the protection of human rights in the maritime domain as flag, coastal and port States. Despite the legal and practical challenges, human security at sea has to emerge as one of the core elements of the maritime security efforts so that the human rights are effectively protected within the EU maritime domain and onboard EU-flagged vessels. 